\title{
Pengaruh Teknik Relaksasi Imajinasi Terbimbing (Guided Imagery) Terhadap Pemenuhan Kebutuhan Tidur Anak Usia Sekolah di Ruang Rawat Inap Anak RSUD Prof. Dr. Ma. Hanafiah SM Batusangkar
}

\author{
Ns. Deswita, M.Kep, Sp. Kep An*a , Dra. Asterina, MS*b , Ummul Hikmah*c \\ *a Pembimbing I Program Studi S1 Ilmu keperawatan \\ Fakultas keperawatan Universitas Andalas \\ *b Pembimbing II Fakultas Kedokteran Universitas Andalas \\ ${ }^{* c}$ Program Studi S1 Ilmu keperawatan Fakultas keperawatan Universitas Andalas
}

\begin{abstract}
The Influence of Guided Imagination Relaxation Techniques (Guided Imagery) toward Fulfillment of Sleeping in School-Age Children in RSUD Prof. Dr. Ma. Hanafiah SM Batusangkar

Sleep disorders are often experienced by children during their hospitalization. Sleep disturbance in a long time will affect a person's physical psychological condition and can cause the length of the healing process. Guided imagery relaxation techniques is a relaxation technique that uses all the senses through audio provided. The purpose of this study was to observe the effect of guided imagery relaxation techniques to fulfill the needs of school-age children to sleep. The design of this study was a quasi experimental design with one group pretest posttest. The sampling technique used purposive sampling the consists of 14 respondents experiencing sleep disorders. The results of this studies using Wilcoxon statistical test showed the influence of guided imagery relaxation techniques to fulfill the needs of school-age children to sleep. With an average increase in sleep duration was 8.42, $p=0.000$ and 0.474 standard deviation. It should be given a guided imagery relaxation techniques, either directly or using media such as mp3 audio in a health service in improving the sleep needs of inpatient children.
\end{abstract}

Key words : Meeting/fulfillment the needs of sleep, guided Imagination

Abstrak : Pengaruh Teknik Relaksasi Imajinasi Terbimbing (Guided Imagery) Terhadap Pemenuhan Kebutuhan Tidur Anak Usia Sekolah Di Ruang Rawat Inap Anak RSUD Prof. Dr. Ma. Hanafiah Sm Batusangkar.

Gangguan tidur sering dialami oleh anak selama menjalani hospitalisasi. Gangguan tidur dalam waktu yang lama akan mempengaruhi kondisi fisik dan psikologis seseorang serta bisa menyebabkan lamanya proses penyembuhan. Teknik relaksasi imajinasi terbimbing (guided imagery) merupakan salah satu teknik relaksasi yang menggunakan semua pancaindera melalui audio yang diberikan. Tujuan penelitian ini adalah untuk melihat pengaruh teknik relaksasi imajinasi terbimbing terhadap pemenuhan kebutuhan tidur anak usia sekolah. Desain penelitian yang digunakan adalah quasi eksperimental design dengan one group pretest posttest. Teknik pengambilan sampel dengan purposive sampling yang terdiri dari 14 orang responden yang mengalami gangguan tidur. Hasil penelitian dengan menggunakan uji statistik wilcoxon menunjukan adanya pengaruh teknik relaksasi imajinasi terbimbing terhadap pemenuhan kebutuhan tidur anak usia sekolah dengan rata-rata peningkatan durasi tidur adalah 8,42, p=0,000 dan standar deviasi 0,474. Perlu diberikan teknik relaksasi imajinasi terbimbing (guided imagery) baik secara langsung ataupun menggunakan media audio seperti mp3 di sebuah pelayanan kesehatan dalam meningkatkan kebutuhan tidur pasien rawat inap anak.

Kata kunci : Teknik relaksasi, Pemenuhan kebutuhan tidur, Imajinasi terbimbing

Tidur merupakan salah satu kebutuhan dasar manusia dan berbeda untuk semua umur. Kebutuhan tidur yang tidak tercukupi akan menyebabkan terjadinya gangguan tidur. Gangguan tidur dapat dialami oleh semua lapisan masyarakat, yang paling sering ditemukan pada anak yang sedang di rawat di rumah sakit. Menurut Irwin, dkk. (1994, 1996); Moldofsky, (1995) dalam
Meltzer, dkk. (2012) mengatakan bahwa anak yang mengalami gangguan tidur selama hospitalisasi akan berpengaruh pada fungsi kekebalan tubuh atau menurunnya daya tahan tubuh dan menyebabkan lamanya proses penyembuhan pasien anak.

Reaksi anak karena dirawat di rumah sakit dipengaruhi oleh beberapa faktor seperti anak harus beradaptasi dengan 
lingkungan yang baru dan asing, harus menjalani kegiatan atau aktivitas rutin rumah sakit, petugas rumah sakit dan orang orang di sekitarnya, nyeri karena tindakan perawatan dan penyakit yang akan berakibat pada pola tidur anak (Rudolph, 2002 dalam Suci dan Kili, 2012).

Gangguan tidur dapat terjadi pada anak dengan manifestasi kesulitan pada saat memulai tidur, mempertahankan tidur, atau gangguan yang berhubungan dengan pernapasan. Penyebab gangguan tidur dapat bersifat internal maupun eksternal yang akan mempengaruhi kualitas dan kuantitas tidur. Bila anak mengalami stres dan mengalami gejala psikologis seperti kecemasan akan membuat respon hipotalamus meningkat sehingga individu yang mengalami kecemasan akan sulit untuk tertidur dan cenderung terjaga (Desita dan Aries, 2011).

Survey American National Sleep Foundation (2006) dalam Frost (2009) menyatakan bahwa selama menjalani hospitalisasi sebanyak $40 \%$ orang tua dan perawat anak yang ikut dalam survei tersebut menyatakan bahwa bayi dan batita mereka tidur kurang dari 12-15 jam/hari seperti yang direkomendasikan oleh para dokter spesialis anak. Anak yang mengalami masalah tidur setiap malam dikeluhkan oleh $40 \%$ orang tua dan sebanyak $64 \%$ mengatakan bahwa dalam satu minggu anak-anak mereka sulit untuk tidur sehingga tidak dapat mencapai kebutuhan tidur seperti yang seharusnya. Sebanyak $25 \%$ orang tua dan perawat anak yang disurvei mengatakan bahwa bayi, batita, dan anak usia prasekolah mereka tampak mengantuk atau lelah pada siang hari (Yuniarti, 2012).

Gangguan tidur dapat diatasi dengan terapi farmakologis dan terapi non farmaklogis. Terapi farmakologis yaitu terapi dengan menggunakan obat-obatan seperti golongan obat hipnotik, antidepresan, terapi hormone melatonin dan agonis melatonin, antihistamin, dan pada kasus-kasus gangguan tidur tertentu seperti sleep apnea yang berat dapat dibantu dengan pemakaian masker oksigen (continuous positive airway pressure) atau tindakan pembedahan jika disebabkan kelemahan otot atas pernapasan. Terapi non farmakologis yaitu terapi yang tidak menggunakan obat seperti stimulus control therapy, paradoxical intention therapy, relaxation therapy, sleep restriction therapy, temporal control therapy, sleep hygiene.

Terapi non farmakologis yang sering digunakan salah satunya adalah teknik relaksasi. Teknik relaksasi yang bisa digunakan salah satunya menurut Black dan Matassarin (1998) yaitu imajinasi terbimbing (guided imagery), dapat bermanfaat untuk menurunkan kecemasan, kontraksi otot dan memfasilitasi tidur. Potter \& Perry (2005) juga menyatakan imajinasi terbimbing dapat meningkatkan tidur.

Teknik imajinasi terbimbing akan sangat efektif pada anak-anak dibanding orang dewasa dan lebih membuka kreativitas dan imajinasi anak karena pada tahap taman kanak-kanak pengembangan imajinasi tampak dengan cara mencoret-coret gambar dengan gerakan kasar penuh tenaga (Hart, 2008 dalam Mariyam dan Sri, 2012). Menurut Masulili (2011) imajinasi terbimbing memberikan manfaat kepada anak untuk belajar rileks, menghilangkan atau merubah perilaku yang tidak diinginkan, meningkatkan manajemen nyeri secara efektif, perilaku pembelajaran yang diinginkan dan baru, menjadi lebih termotivasi dalam menghadapi suatu masalah, mengatasi atau menghilangkan marah, mengolah situasi stres dan kecemasan, serta untuk meningkatkan tidur.

Survei awal penelitian di Ruang Rawat Inap Anak RSUD Hanafiah Batusangkar orang tua mengatakan anak menangis disaat bangun dari tidur dan tidak segar dalam kesehariannya. Anak sering tertidur setelah 30 menit sampai 60 menit dari waktu biasanya anak tidur, bahkan lebih, sering terbangun dari tidurnya karena nyeri dan merasa tidak nyaman dengan lingkungan rumah sakit, tidur siang yang biasa dilakukan juga tidak terpenuhi karena aktifitas di rumah sakit.

Empat dari enam orang tua mengatakan bahwa anak mereka tidur kurang dari 
kebutuhan tidurnya seperti anak usia 4 tahun tidur 8-9 jam per hari dan anak usia 8 tahun tidur hanya 6-8 jam perhari selama perawatan. Perawat yang berada di ruang rawat inap anak mengatakan bahwa anakanak selalu mengalami gangguan tidur saat hari pertama sampai hari ketiga.

\section{METODE}

Penelitian ini merupakan penelitian quasi eksperimental dengan rancangan penelitian yang digunakan adalah pretest-posttest with one group design. Penelitian ini melihat pengaruh teknik imajinasi terbimbing terhadap pemenuhan kebutuhan tidur anak di ruang rawat inap anak RSUD Prof. Dr. Ma. Hanafiah SM Batusangkar yaitu kelompok intervensi dilakukan pengukuran nilai kebutuhan tidur sebelum diberikan teknik imajinasi terbimbing (pretest) kemudian diberikan intervensi teknik imajinasi terbimbing satu kali sehari sebelum tidur malam selama tiga hari
Berdasarkan fenomena dan hasil survei diatas, peneliti tertarik untuk melakukan penelitian tentang Pengaruh Teknik Relaksasi Imajinasi Terbimbing (Guided Imagery) Terhadap Pemenuhan Kebutuhan Tidur Anak Usia Sekolah di Ruang Rawat Inap Anak RSUD Prof. Dr. Ma. Hanafiah Batusangkar.

berturut-turut, setelah itu pada hari keempat dilakukan kembali pengukuran kebutuhan tidur setelah intervensi (posttest). Teknik pengambilan sampel pada penelitian ini adalah Non Probability Sampling yaitu Purposive Sampling. Sampel yang digunakan adalah sebanyak 14 orang dan sebelum diberikan intervensi, dilakukan screening untuk menentukan anak mengalami gangguan tidur atau tidak, mengalami stres, cemas dan nyeri. Responden yang mengalami gangguan tidur, stres, cemas dan nyeri berat berdasarkan hasil screening tidak diberikan intervensi teknik relaksasi imajinasi terbimbing.

\section{HASIL DAN PEMBAHASAN}

\section{Karakteristik Anak}

Tabel 5.1 Distribusi frekuensi karakteristik responden berdasarkan jenis kelamin dan usia di ruang rawat inap anak RSUD Prfo. Dr. Ma. Hanafiah SM Batusangkar.

\begin{tabular}{|c|c|c|c|}
\hline No & Jenis Kelamin & Frekuensi & Persentase (\%) \\
\hline 1 & Laki-laki & 9 & 64.3 \\
\hline 2 & Perempuan & 5 & 35.7 \\
\hline & Jumlah & 14 & 100.0 \\
\hline No & Usia & Frekuensi & Persentase (\%) \\
\hline 1 & 6 tahun & 1 & 7.1 \\
\hline 2 & 7 tahun & 2 & 14.3 \\
\hline 3 & 8 tahun & 2 & 14.3 \\
\hline 4 & 9 tahun & 2 & 14.3 \\
\hline 5 & 10 tahun & 3 & 21.4 \\
\hline 6 & 11 tahun & 1 & 7.1 \\
\hline 7 & 12 tahun & 3 & 21.4 \\
\hline & Jumlah & 14 & 100.0 \\
\hline
\end{tabular}


Pada tabel diatas dapat dilihat bahwa dari 14 responden, responden yang lebih dominan pada penelitian ini adalah lakilaki 9 orang $(64,3 \%)$ dan perempuan 5 orang $(35,7 \%)$ dan responden pada penelitian ini berada pada rentang usia 612 tahun dengan responden usia 10 dan 12 tahun $(21,4 \%)$ lebih banyak dalam penelitian ini.

\section{Analisis Univariat}

Grafik 5.1 Distribusi frekuensi durasi tidur sebelum dan sesudah diberikan teknik relaksasi imajinasi terbimbing di di ruang rawat inap anak RSUD Prfo. Dr. Ma. Hanafiah SM Batusangkar.

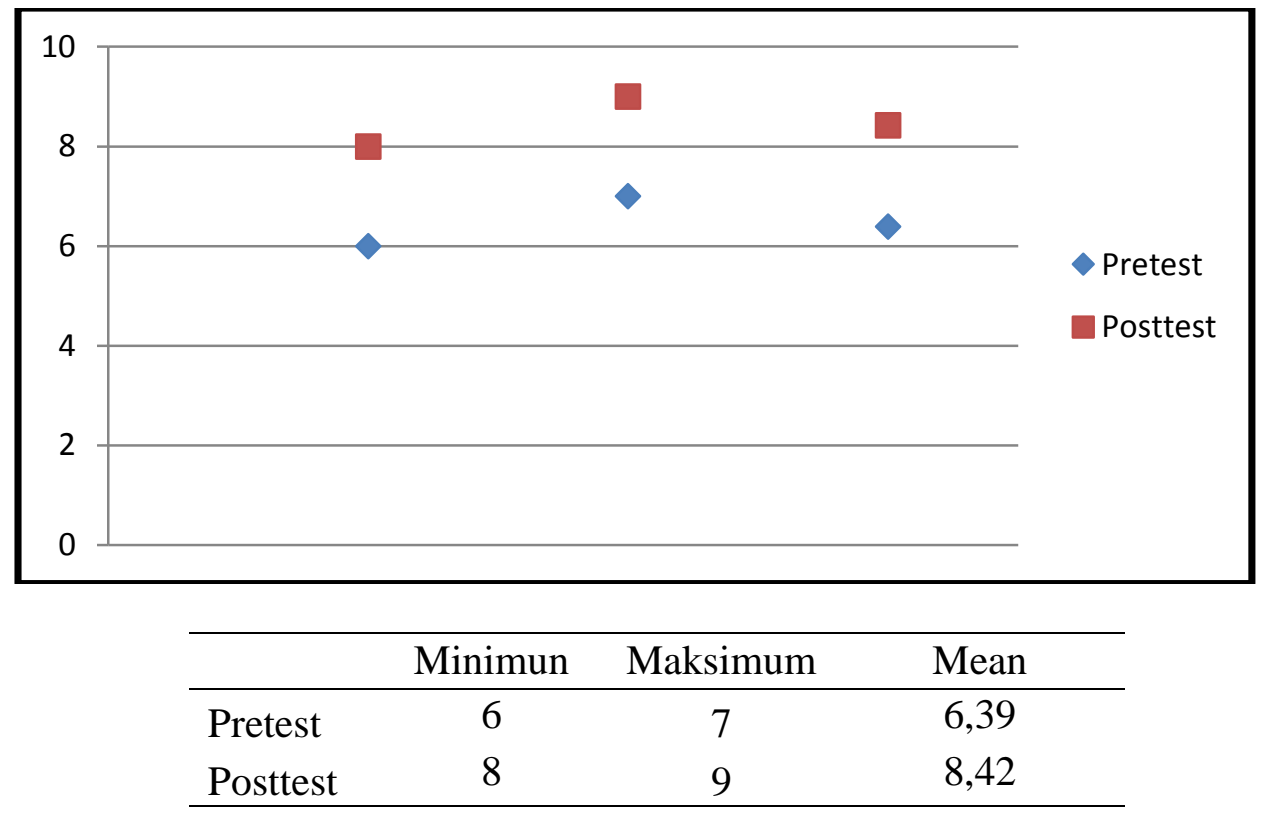

Berdasarkan grafik 5.1 diatas, dapat dilihat bahwa durasi tidur responden sebelum diberikan intervensi imajinasi terbimbing antara 6-7 jam yang menunjukan bahwa responden mengalami gangguan tidur dan tidak terpenuhi kebutuhan tidurnya, dengan keluhan sering terbangun pada malam hari, sulit untuk memulai tidur, mengantuk di siang hari, merasa lelah dan gelisah.

Durasi tidur responden setelah diberikan intervensi meningkat menjadi 8-9 jam yang menunjukan telah tercukupinya kebutuhan tidur responden dengan tidak terbangun pada malam hari, tidak sering menguap atau mengantuk pada siang hari, tidak mengalami gangguan mood/perasaan, tidak susah untuk tidur kembali, tidak sulit untuk memulai tidur, tidak rewel dan gelisah, serta tercukupinya jumlah jam tidur anak. Ratarata terjadi peningkatan durasi tidur dari 6,39 menjadi 8,42 .

\section{Analisis Bivariat}

Sebelum dilakukan analisis bivariat, dilakukan uji normalitas untuk menentukan uji yang akan digunakan dalam menganalisis data. Hasil uji normalitas dengan menggunakan Shapiro-Wilk didapatkan nilai pretest $\mathrm{p}=0,001$ dan posttest $\mathrm{p}=0,001$, dan dilakukan uji wilcoxon.

Tabel 5.2 Pengaruh Teknik Relaksasi Imajinasi Terbimbing Terhadap Pemenuhan Kebutuhan Tidur Di Ruang Rawat Inap Anak RSUD Prof. Dr. Ma. Hanafiah SM Batusangkar 
Mean Rank

\begin{tabular}{lllll} 
& n & & $\begin{array}{c}\text { Sum of } \\
\text { Ranks }\end{array}$ & P Value \\
& & & & \\
\hline $\begin{array}{l}\text { Durasi Tidur Posttest - } \\
\text { Durasi Tidur Pretest }\end{array}$ & 14 & 7.50 & 105.00 & 0,000 \\
\hline
\end{tabular}

Hasil uji bivariat dengan wilcoxon didapatkan nilai $\mathrm{p}<0,005(\mathrm{p}=0,000)$, dengan mean 8,42 , mean rank 7,50 dan standar deviasi 0,474 maka dapat disimpulkan terdapat perbedaan yang signifikan antara jumlah durasi tidur pasien di rawat inap anak sebelum dan sesudah diberikan intervensi, sehingga terdapat pengaruh teknik relaksasi imajinasi terbimbing terhadap pemenuhan kebutuhan tidur di ruang rawat inap anak RSUD Prof. Dr. Ma. Hanafiah SM Batusangkar.

Hasil penelitian dengan uji statistik Wilcoxon didapatkan bahwa dari 14 orang responden, semua anak mengalami gangguan tidur dengan rata-rata 6,39 dan standar deviasi 0,446 sebelum dilakukan intervensi. Setelah dilakukan intervensi, terjadi peningkatan pemenuhan kebutuhan tidur berupa durasi tidur anak yaitu 8,42 dengan standar deviasi 0,474, mean rank 7,50 dan nilai $\mathrm{p}=0,000(\mathrm{p}<0,005)$ yang menunjukan terdapat perbedaan yang signifikan antara jumlah durasi tidur sebelum dan sesudah diberikan teknik relaksasi imajinasi terbimbing yang dilakukan pada anak usia sekolah di ruang rawat inap anak RSUD Prof. Dr. Ma. Hanafiah SM Batusangkar.

Audio imajinasi terbimbing yang diberikan kepada anak pada penelitian ini berisikan hal-hal yang sangat dekat dengan kehidupan anak, imajinasi yang lebih bersifat nyata atau objek yang sudah mereka kenali, sehingga anak merasa lebih senang dan nyaman saat diberikan terapi. Hal ini dapat terjadi karena menurut Hart (2008 dalam Mariyam dan Sri, 2012), teknik imajinasi terbimbing akan sangat efektif pada anakanak dibanding orang dewasa dan lebih membuka kreativitas serta imajinasi anak karena pada saat usia sekolah dasar umumnya seorang anak mulai melakukan proses belajar beranjak dari hal-hal yang konkrit atau yang dapat dilihat, didengar, dan diotak atik dengan titik hasil penekanan lingkungan sebagai sumber belajar yang riil dan nyata.

Gorman (2010) juga mengatakan bahwa imajinasi terbimbing juga bermanfaat bagi anak-anak. Imajinasi terbimbing berguna untuk siapa saja dan dapat dilakukan dilingkungan yang tenang dan kondusif untu relaksasi. Pemberian imajinasi terbimbing secara terus menerus dalam waktu yang singkat atau dalam waktu yang lama bisa membuat tubuh menjadi sehat. Imajinasi terbimbing juga mempengaruhi emosional, mental, fisik dan rohani yang akan meningkatkan kualitas hidup seseorang (Gorman, 2010). Emosional, mental, fisik dan rohani yang dipengaruhi oleh imajinasi terbimbing akan membuat anak menjadi rileks dan meningkatkan kebutuhan tidur anak.

Selama pemberian teknik relaksasi imajinasi terbimbing 50\% anak langsung tertidur dan $50 \%$ lagi tidak tertidur. Hal ini bisa terjadi karena faktor lain yang mempengaruhinya seperti nyeri yang dirasakan secara-tiba saat intervensi berlangsung. Anak yang tidak langsung tertidur, berdasarkan hasil wawancara dengan orang tua dan observasi, akan tertidur kurang dari 15 menit. Ini menunjukan bahwa intervensi imajinasi terbimbing memberikan respon relaksasi kepada anak sebelum tertidur, sedangkan anak yang langsung tertidur, mendapatkan manfaat teknik relaksasi iamjinasi terbimbing sebagai relaksasi serta peningkatan lama jatuh tidur anak.

Penelitian pengaruh teknik relaksasi imajinasi terbimbing terhadap pemenuhan tidur baik dari segi kuantitas maupun kualitas telah dilakukan oleh beberapa 
peneliti. Penelitian Saputri (2011), diperoleh hasil bahwa pemenuhan kebutuhan tidur secara kualitas $76,5 \%$ terpenuhi dan rata-rata pemenuhan kebutuhan tidur secara kuantitas adalah 5 jam. Penelitian ini juga dilakukan oleh Kamora, dkk. (2012), hasil pretest ratarata jam tidur pada kelompok eksperimen dan kontrol adalah 2,6 jam, kemudian setelah dilakukan intervensi pemberian teknik relaksasi guided imagery pada kelompok eksperimen rata-rata jam tidur dalam sehari menjadi 5 jam dengan nilai $\mathrm{p}<0,05(0,000)$.

Sejalan dengan penelitian ini, penelitian oleh Andari (2013) di RSUD Solok tentang pengaruh teknik relaksasi Guided imagery terhadap kualitas tidur pasien DM di ruang interne RSUD Solok tahun 2013, 100\% responden mengalami peningkatan kualitas tidur dengan nilai p-value 0,000. Kalsum, dkk. (2007) juga melakukan penelitian tentang pengaruh teknik guided imagery terhadap penurunan tingkat kecemasan pada klien wanita dengan gangguan tidur (insomnia) usia 20-25 tahun di Kecamatan Lowokwaru Malang juga memberikan pengaruh yang sangat besar mengurangi kecemasan dengan gangguan tidur(insomnia) pada wanita.

Menurut Gorman (2010) tentang The Power Of Guided Imagery menyatakan bahwa imajinasi telah lama digunakan oleh masyarakat pada zaman kuno dan mempercayai bahwa imajinasi positif akan bisa mempercepat penyembuhan. Hal ini didukung oleh pernyataan Hippocrates dan Aristoteles bahwa kekuatan imajinasi bermanfaat untuk jantung, otak dan organ lainnya. Guided imagery menggunakan panduan kata-kata seseorang untuk membantu dalam berimajinasi, membawa perasaan ke tempat yang berbeda-beda serta merasa nyaman dengan kondisi tubuh yang baik. Pola nafas yang teratur akan membimbing untuk mengikuti irama yang lambat menuju relaksasi yang dalam. Suatu respon terjadi di mana tubuh bergerak ke pola-pola baru relaksasi, tubuh melakukan hal ini secara alami. Kekuatan dari imajinasi terbimbing ini adalah menggunakan semua indera.
Pemberian latihan teknik relaksasi imajinasi terbimbing sangat membantu dalam memenuhi kebutuhan tidur anak dimana anak tersebut mengalami gangguan tidur yang bisa disebabkan oleh lingkungan, mengalami kecemasan, nyeri dan tindakan perawatan lainya. Pemberian latihan secara teratur akan membuat anak belajar untuk rileks dari bayangan yang mereka bayangkan dan menurunkan reaksinya terhadap stres dan membuat anak merasa nyaman dalam menjalani hospitalisasi. Cara ini akan bermanfaat untuk memenuhi kebutuhan tidur anak baik secara kuantitas maupun kualitasnya.

\section{KESIMPULAN \& SARAN}

Berdasarkan penelitian yang dilakukan tentang pengaruh teknik relaksasi imajinasi terbimbing terhadap pemenuhan kebutuhan tidur anak usia sekolah di ruang rawat inap anak RSUD Prof. Dr. Ma. Hanafiah SM Batusangkar, dapat diambil kesimpulan bahwa pemenuhan kebutuhan tidur anak sebelum diberikan teknik relaksasi imajinasi terbimbing tidak terpenuhi semuanya dan mengalami gangguan tidur dan terjadi peningkatan pemenuhan kebutuhan tidur anak setelah diberikan teknik relaksasi imajinasi terbimbing dengan nilai $\mathrm{p}=0,000$ dan rata-rata 8,42 .

Bagi Ilmu Keperawatan, dapat dijadikan sebagai masukan bagi ilmu keperawatan dan referensi bagi penelitian selanjutnya mengenai teknik relaksasi imajinasi terbimbing.

Bagi Rumah Sakit, sebagai masukan bagi tenaga keperawatan dalam memberikan asuhan keperawatan berupa teknik relaksasi imajinasi terbimbing untuk mengatasi gangguan tidur di ruang rawat inap khususnya ruang rawat inap anak karena teknik relaksasi imajinasi terbimbing mampu memberikan ketenangan dan kenyamanan yang akan membantu penderita gangguan tidur mendapatkan tidur yang baik dan berkualitas. 
Bagi Peneliti Selanjutnya untuk bisa melanjutkan penelitian mengenai efektivitas lama pemberian teknik relaksasi imajinasi terbimbing terhadap lama jatuh tidur anak, baik itu pada pasien anak di rumah sakit atau anak yang mengalami gangguan tidur di rumah.

\section{DAFTAR PUSTAKA}

Andari, U. (2013). Pengaruh Teknik Relaksasi Imajinasi Terbimbing (Guided Imagery Terhadap Kualitas Tidur Pasien Diabetes Melitus di RSUD Solok. Skripsi. Padang: Fakultas Keperawatan Universitas Andalas.

Anggraini, T.L. (2012). Penggunaan Audio Recorded Guided Imagery Therapy Untuk Mengurangi Nyeri Abdominal Fungsional Pada Anak. Depok : Program Magister Fakultas Ilmu Keperawatan Peminatan Keperawatan Anak Universitas Indonesia.

Ashra, F. dkk. (2012). Pengaruh Teknik Relaksasi: Imajinasi Terbimbing Terhadap Pengurangan Tingkat Nyeri Pada Pasien Postoperasi Apendiktomi Di Ruang Rawat Inap Bedah Rsud Prof. Dr. Ma. Hanafiah SM Batusangkar Tahun 2012.

Colella. (2009). The Effect of Guided Imagery Therapy in Children with Functional Abdominal Pain in Quiescent Inflammatory Bowel Diseases (IBD).

Crampton, M. (2005). Guided Imagery: A Psychosynthesis Approach. Canadian Institute of Psychosynthesis.

Dahlan, M.S. (2013). Statistik Untuk Kedokteran dan Kesehatan: Deskriptif, Bivariat dan Multivariat Dilengkapi Aplikasi dengan Menggunakan SPSS. Jakarta : Salemba Medika.

Garliah, L. (2009). Pengaruh Tidur Bagi Perilaku Manusia. Fakultas Psikologi Universitas Sumatera Utara.
(2008). Hubungan Informasi Tentang Tindakan Keperawatan Dengan Pola Tidur Pasien. Universitas Sumatera Utara.

Gorman, B. (2010). The Power of Guided Imagery. University of Minnesota : Mandala

Hidayat, A. A. A. (2011). Metode Penelitian Keperawatan dan Teknik Analisis Data. Jakarta: Selemba Medika

Kalsum, Dr.U. dkk. (2007). Pengaruh Teknik Guided Imagery Terhadap Penurunan Tingkat Kecemasan Pada Klien Wanita Dengan Gangguan Tidur (Insomnia) Usia 20-25 Tahun Di Kelurahan Ketawanggede Kecamatan Lowokwaru Malang. Majalah Kesehatan FKUB.

Kamora, dkk. (2012). Efektifitas Teknik Relaksasi Guided Imagery Terhadap Pemenuhan Rata-Rata Jam Tidur Pasien Di Ruang Rawat Inap Bedah. Riau: Universitas Riau.

Mariyam, A.K. (2008). Hubungan antara Stress Hospitalisasi Pada Anak Usia Sekolah Terhadap Perubahan Pola Tidur Anak Selama di Rawat di BRSD RAA Soewondo Pati.

McLaughlin, M. dan Allen, M.B. (2000). Guided Comprehension: a teaching model for grades 3-8 Visualizing. Newark, Delaware: International Reading Association.

Meltzer, L.J. de et al. (2012). Patient and Parent Sleep In a Children's Hospital. Pediatric Nursing/March-April 2012, 38 (2). 2 Maret 2014. dari https://www.pediatricnursing.net/ce/20 14/article38026471.pdf

Natalita, C. dkk. (2011). Skala Gangguan Tidur untuk Anak (SDSC) sebagai Instrumen Skrining Gangguan Tidur pada Anak Sekolah Lanjutan Tingkat Pertama. Sari Pediatri, 12(6). Departemen Ilmu Kesehatan Anak, Rumah Sakit Cipto Mangunkusumo Fakultas Kedokteran Universitas Indonesia.

Notoadmojo, S. (2005). Metodologi Penelitian Kesehatan. Jakarta : PT Rineka Cipta 
Nursalam. (2008). Konsep dan Penerapan Metodologi Penelitian Ilmu Keperawatan. Jakarta: Salemba Medika.

Pariman. (2009). Guided Imagery (Sebuah Pendekatan Psikosintesis) Untuk Penurunan Depresi Pada Penderita Kanker. Fakultas Psikologi Universitas Diponegoro Semarang.

Potter, A \& Perry, A. 2005. Buku ajar fundamental keperawatan; konsep, proses, dan praktek, vol.2, edisi keempat. Jakarta: EGC.

Rahayu, U. dkk. (2010). Pengaruh Guide Imagery Relaxation Terhadap Nyeri Kepala Pada Pasien Cedera Kepala Ringan. Laporan Akhir Penelitian. Fakultas Ilmu Keperawatan Universitas Padjadjaran

Reznick, C.PhD. (2009). The Power of Your Child's Imagination: How to Transform Stress and Anxiety into Joy and Success. Peringee.

Saputri, K.D. (2011). Pengaruh Teknik Relaksasi Guided Imagery Terhadap Pemenuhan Kebutuhan Tidur Lansia di Panti Sosial Trisna Werdha Melania Tanggerang. Jakarta : Universitas Pembangunan.

Sugiyono. (2011). Metode Penelitian Kualitatif dan Kuantitatif. Bandung: Alfabeta.

Sutrimo, A.. (2012). Pengaruh Guided Imagery and Music (GIM) terhadap Kecemasan Pasien Pre Operasi
Section Caesaria (SC) di RSUD Banyumas.

Tanjung, MF C dan Rini, S. (2004). Masalah Tidur pada Anak. Sari Pediatri, 6 (3), 138-142.

Tell, P. (2007). The Power of a Cild's Imagination. People magazine. 2 Maret 2014. dari www.PattiTeel.com.

Utami, M. A. (2013). Pengaruh Guided Imagery Terhadap Nyeri Menstruasi. Jurnal Online Psikologi, 01 (02). Fakultas Psikologi Universitas Muhammadiyah Malang.

Vygotsky, L.S. (2004). Imagination and Creativity in Childhood. Journal of Russian and East European Psychology, 42 ( 1), 7-97.

Wong, D.L. (2008). Buku Ajar Keperawatan Pediatrik Volume 1. Edisi Keenam. Jakarta: EGC.

Wijayanti, P.D. (2009). Faktor - Faktor Yang Berhubungan Dengan Regresi Anak Prasekolah Saat Hospitalisasi Di Rumah Sakit Anak Dan Bunda Harapan Kita Jakarta. Jakarta : Program Studi Ilmu Keperawatan Fakultas Kedokteran Dan Ilmu Kesehatan Uin Syarif Hidayatullah

Yuniartini, dkk. (2009). Pengaruh Terapi Bercerita Terhadap Kualitas Tidur Anak Usia Prasekolah Yang Menjalani Hospitalisasi Di Ruangan Perawatan Anak RSUP Sanglah Denpasar. Program Studi Ilmu Keperawatan Fakultas Kedokteran Universitas Udayana. 